\title{
FDI and its role in economic development: Do we need a new agenda?
}

Citation for published version (APA):

Lall, S., \& Narula, R. (2004). FDI and its role in economic development: Do we need a new agenda? MERIT, Maastricht Economic Research Institute on Innovation and Technology. MERIT-Infonomics Research Memorandum Series No. 019 https://doi.org/10.26481/umamer.2004019

Document status and date:

Published: 01/01/2004

DOI:

10.26481/umamer.2004019

Document Version:

Publisher's PDF, also known as Version of record

\section{Please check the document version of this publication:}

- A submitted manuscript is the version of the article upon submission and before peer-review. There can be important differences between the submitted version and the official published version of record.

People interested in the research are advised to contact the author for the final version of the publication, or visit the DOI to the publisher's website.

- The final author version and the galley proof are versions of the publication after peer review.

- The final published version features the final layout of the paper including the volume, issue and page numbers.

Link to publication

\footnotetext{
General rights rights.

- You may freely distribute the URL identifying the publication in the public portal. please follow below link for the End User Agreement:

www.umlib.nl/taverne-license

Take down policy

If you believe that this document breaches copyright please contact us at:

repository@maastrichtuniversity.nl

providing details and we will investigate your claim.
}

Copyright and moral rights for the publications made accessible in the public portal are retained by the authors and/or other copyright owners and it is a condition of accessing publications that users recognise and abide by the legal requirements associated with these

- Users may download and print one copy of any publication from the public portal for the purpose of private study or research.

- You may not further distribute the material or use it for any profit-making activity or commercial gain

If the publication is distributed under the terms of Article $25 \mathrm{fa}$ of the Dutch Copyright Act, indicated by the "Taverne" license above, 


\section{MERIT-Infonomics Research Memorandum series}

FDI and its role in economic development:

Do we need a new agenda?

Sanjaya Lall \& Rajneesh Narula

2004-019

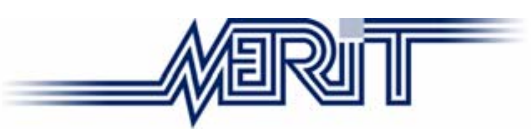

MERIT - Maastricht Economic Research Institute on Innovation and Technology

PO Box 616

6200 MD Maastricht

The Netherlands

T: +31433883875

F: +31433884905

http://www.merit.unimaas.nl

e-mail:secr-merit@merit.unimaas.nl

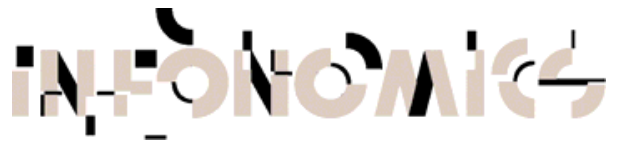

International Institute of Infonomics

c/o Maastricht University

PO Box 616

6200 MD Maastricht

The Netherlands

T: +31433883875

F: +31453884905

http://www.infonomics.nl e-mail: secr@infonomics.nl 


\title{
FDI AND ITS ROLE IN ECONOMIC DEVELOPMENT: DO WE NEED A NEW AGENDA?
}

\author{
Sanjaya Lall \\ University of Oxford \\ International Development Centre, Queen Elizabeth House \\ 21 St Giles, Oxford OX1 3LA, UK \\ Rajneesh Narula \\ University of Reading Business School, Department of Economics \\ PO Box 218, Whiteknights, Reading RG6 6AA, UK
}

\section{Forthcoming, special issue European Journal of Development Research,2004, Vol Acknowledgements \\ 16}

Earlier drafts of the papers included in this special issue were presented at a workshop organised by The Centre for Technology, Innovation and Culture (TIK) at the University of Oslo, Understanding FDI-Assisted Economic Development from the 22nd to the 25th May 2003. We gratefully acknowledge financial support from two Norwegian Research Council-funded projects, "The North Versus the South in a Globalising World" and "Globalisation as a Transformative Force”. We gratefully acknowledge the support of Helge Hveem, Brian Portelli and Christine Sole in organisational matters. This paper has benefited greatly from comments and discussions of the various participants. Comments on an earlier draft by Brian Portelli, Tanja Sinozic and Paola Criscuolo have also contributed to this paper.

7597 words

keywords: FDI, spillovers, industrial policy, governments, development, WTO, globalisation, developing countries, liberalisation. 


\title{
FDI AND ITS ROLE IN ECONOMIC DEVELOPMENT: DO WE NEED A NEW AGENDA?
}

\author{
Sanjaya Lall and Rajneesh Narula
}

\begin{abstract}
Despite globalisation, the essential role of FDI in economic development has not changed. However, many mechanisms and dynamics of FDI-assisted development have changed: there is greater variation in the kinds of FDI, the benefits each offers, and the manner in which each interacts with the host economy. This introductory article attempts to place the discussions and issues raised in this special issue of The European Journal of Development Research within the wider literature on FDI and development. The papers here analyse the role of MNEs in industrial development in a 'learning system' perspective. They also analyse the policy tools available for using FDI for economic development in a liberalising, post-WTO world, and the constraints to doing this. While this is a nascent debate, this special issue points to a variety of 'soft' policy options that provide a pragmatic response to the complexities of globalisation.
\end{abstract}




\section{Introduction}

The last two or three decades have seen a significant policy shift in the developing world, from inward-looking import substitution to outward-looking, market determined strategies. The reasons for this shift are complex, but mainly have to do with the inefficiencies of import substitution, the growth of globalised production and the success of the export-oriented Asian newly industrialised economies (NIEs). One key feature of liberalisation has been greater openness to foreign direct investment (FDI) as a means of acquiring technologies, skills and access to international markets, and of entering dynamic trade and production systems internal to MNEs.

The role of the MNE as a source of capital and technology has grown over time, as other sources of capital have become scarcer or more volatile and technical change has accelerated. MNEs continue to dominate the creation of technology; indeed, with the rising costs and risks of innovation their importance has risen (with the exception of very new technology areas). They have also become more mobile, searching the world for lower cost, more efficient production sites and for new markets. The interaction of technical change (with its need for more and higher skills and better infrastructure) with greater FDI mobility has not reduced the need for local capabilities in developing countries. On the contrary, entry levels for attracting (non resource-extracting) FDI have risen, and investors (activities facing world competition) are focusing on countries with strong local capabilities. Mobile MNEs, in other words, seek strong complementary factors wherever they locate. There is no conflict over the long term between inward FDI and domestic capabilities.

With this realisation, and with the growing role of MNEs in economic life in most countries, most developing country governments have removed restrictions on FDI inflows. International donors and development agencies focus more on promoting private rather than public capital flows as catalysts of long-term development. The international 'rules of the game' reinforce these trends, setting up a legal framework for minimising policy interventions in FDI. The main actions so far cover national 
treatment for MNEs and the removal of performance requirements on them (for example, on local content, technology transfer or export obligations).

However, liberalisation has not always increased FDI inflows into host developing countries. The reason is simple. The removal of restrictions on FDI does not create the complementary factors that MNEs need; it only allows them to exploit existing capabilities more freely. Thus, FDI response tends to be most vigorous where local capabilities are strong when liberalization takes place, and feeblest where they are weak (of course, excluding resource extraction). Similarly, over time, FDI inflows rise where local capabilities are strengthened and new capabilities are created, they stagnate or fall where they are not. This still has not, surprisingly, been internalised in policy recommendations on FDI in developing countries - much of this still proposes liberalization not just as a necessary but also as a sufficient condition for attracting FDI and extracting most development benefits from it.

There is thus a need to look afresh at the role of MNEs and FDI policies in developing countries. This is the objective of this special issue, and one which the current paper seeks to highlight by placing these contributions within the context of the literature on FDI and development. The papers here indicate that much of what we already know about FDI in economic development remains valid. It is clear, for instance, that the creation of linkages and the internalisation of spillovers from MNE activities still depend on local absorptive capacity. However, we know more now on how these mechanisms work. Complementary assets in the host country reflect its stage of development, in turn influenced by its history, geography and business systems. Some papers in this issue increase our understanding of the nature of absorptive capacities in a 'systems of learning' perspective.

This special issue also analyses the FDI policy tools, constraints and options for host countries in the face of the changing global economy. How do countries respond to the limitations on traditional policy tools placed by WTO protocols like SCM, TRIPS and so on? Several papers point to the 'soft' policy options that may provide an appropriate response to the complexities of globalisation. 


\section{Development Constraints and Opportunities Offered by FDI}

The Washington consensus holds, in broad terms, that markets for knowledge are efficient, and that FDI flows will - ceteris paribus - generate positive externalities for domestic firms. This presumes that all MNE activity offers similar spillovers and development benefits. Its focus is thus mainly on the quantity of FDI rather than its quality. There are four points here that we must qualify.

The competence and scope of subsidiaries: The quality of FDI spillovers depends on the scope and competence of the subsidiary. These depend partly on factors internal to MNEs, including their internationalization strategy, the role of particular affiliates in their global system and the motivation for their investment. Internal strategies interact with host country capabilities and resources [Benito et al 2003]. Affiliates undertaking complex activities need high levels of local competence: advanced specialised skills, strong industrial and service firms and clusters, and strong support institutions. Where host countries cannot provide high level local assets, MNEs will not set up high quality affiliates. For instance, R\&D activities concentrate in the few locations that can provide the advanced resources and institutions.

However, once MNEs establish operations in a country, affiliates often develop new capabilities: thus, the sophistication of affiliates also reflects how long they have been in operation, as documented for East Asia [Rasiah 1994, 1995]. However, such upgrading is not automatic or universal: affiliates have build upon advantages that already exist in the host economy - local capabilities matter [Ritchie 2002]. Over time, the upgrading of affiliates has generally responded to improvements in domestic capabilities. Mortimore \& Vergara find that the nature of a foreign investment depends initially on the host country's technological, human resource and supplier capabilities. They examine the case of Intel in Costa Rica and Toyota in Mexico and argue that in the case of Costa Rica both the lead MNE and the host country were able to achieve their respective objectives. Mexico, on the other hand, was not able to capitalise on the opportunities provided by Toyota's investment. 
While the scope of affiliate activities can be modified rapidly, developing new capabilities takes time. Foreign investments in high value-added activities (needing high competence levels) tend to be 'location-sticky'. MNEs undertake sequential investments (and in building higher levels of competences) in locations that provide sub-optimal returns but where they have prior experience [Hagedoorn and Narula 2001].

Blomstrom and Kokko (1997) suggest that host country characteristics that influence the extent of linkages are market size, local content regulations and the size and technological capability of local firms. They argue that linkages increase over time as the skill level of local entrepreneurs grows, new suppliers emerge and local content increases [see also Driffield and Noor 1999, McAleese and McDonald 1978, Gorg and Ruane 1998, Scott-Kennel and Enderwick 2001]. Nonetheless, there are many instances where upgrading, linkages and spillovers have not grown over time.

The motive for the investment: The motive for a foreign investment is crucial in determining how linkages and externalities develop. There are four main motives for investment: 1) seek natural resources; 2) seek new markets; 3) restructure existing foreign production and 4) seek new strategic assets [Narula and Dunning 2000]. These can be placed into two categories. The first includes the first three motives: asset-exploiting, to generate economic rent by using existing firm-specific assets. The second is the fourth motive: asset-augmenting, to acquire new assets that protect or enhance existing assets. In general, developing countries are unlikely to attract the second category of FDI; they primarily attract the first category.

The relative importance of each motive partly reflects the stage of economic development [Narula and Dunning 2000, Narula, 1996, 2004]. Least developed countries would tend to have mainly resource-seeking FDI and countries at the catching-up stage mostly market-seeking FDI. Efficiency-seeking investments, with the most stringent capability needs, will tend to focus on the more industrialised developing economies (though three or four decades ago they went to countries with 
relatively low capabilities, e.g. the electronics industry in Southeast Asia in the 1970s).

Not all affiliates offer the same spillovers to host economies. A sales office, for instance, may have a high turnover and employ many people, but its technological spillovers will be limited relative to a manufacturing facility. Likewise, resourceseeking activities like mining tend to be capital intensive and provide fewer spillovers than market-seeking manufacturing FDI. During import substitution, most MNEs set up miniature replicas of their facilities at home, though many functions were not reproduced (they were 'truncated'). The extent of truncation, however, varied by host country. The extent most important determinants of truncation - and thus the scope of activities and competence of the subsidiary - were market size and local industrial capabilities [Dunning and Narula 2004]. Countries with small markets and weak local industries had the most truncated subsidiaries, often only single-activity subsidiaries (sales and marketing or natural resource extraction). Larger countries with domestic technological capacity (such as Brazil and India) had the least truncated subsidiaries, often with R\&D departments.

With liberalisation, MNE strategies on affiliate competence and scope have changed in four ways [Dunning and Narula 2004]. First, there has been investment in new affiliates. Second, there has been sequential investment in upgrading existing subsidiaries. Third, there has been some downgrading of subsidiaries, whereby MNEs have divested in response to location advantages elsewhere or reduced the level of competence and scope of subsidiaries. Fourth, there has been some redistribution of ownership as the result of privatisation or acquisitions of local private firms. In many, but certainly not all, cases this also led to a downgrading of activities.

MNEs are taking advantage of liberalisation to concentrate production capacity in a few locations, exploiting scale and agglomeration economies, favourable location and strong capabilities. Some miniature replicas have been downgraded to sales and marketing affiliates, with fewer opportunities for spillovers. Countries that receive FDI with the highest potential for capability development are, ironically, those with 
strong domestic absorptive capacities. The paper by Barnes \& Lorentzen on South Africa shows that domestic capacity - in the form of infrastructure or an efficient domestic industrial sector - is a primary determinant of high competence affiliates. They base their analysis on eight case studies in the South African automotive sector, and show that indigenous firms can compete with MNEs, and - given the appropriate domestic capabilities and infrastructure - can maintain and improve their competitive advantages through indigenous innovation.

Like South Africa, other countries have succeeded in attracting such FDI, notably Mexico and the Caribbean Basin [ECLAC 2000, 2001, Mortimore 2000]. In addition to providing a threshold level of domestic capabilities and infrastructure, these countries have invested in developing their knowledge base (although to a lesser extent in the case of Mexico). Mortimore (2000) argues much of this FDI has created export platforms for MNEs with limited benefits for the host countries [ECLAC 2001]. This is a point reiterated by Mytelka \& Barclay in the case of Trinidad, where FDI has not been leveraged to develop skills and capabilities of local downstream and supporting firms. The state has largely failed to act as a facilitator to stimulate and support domestic absorptive capacities and linkages with MNE affiliates.

MNE linkages: FDI transfers technology to local firms in four ways: backward linkages, labour turnover, horizontal linkages and international technology spillovers. Studies of backward linkages have identified various determinants, including those internal to MNEs and those associated with host economies. The ability of the host economy to benefit from MNE linkages have been found to depend crucially on the relative technological capabilities of recipient and transmitter: the greater the distance between them, the lower the intensity of linkages.

Again, MNE motives and strategies matter. Domestic market oriented affiliates generally purchase more locally than export-oriented firms because of lower quality requirements and technical specifications [Reuber et al. 1973, Altenburg 2000]. MNE affiliates are more likely to be integrated with host countries where they source relatively simple inputs [Ganiatsos 2000, Carillo 2001]. Rodriguez-Clare (1996) 
argues that MNEs create more linkages when they use intermediate goods intensively, communication costs between parent and affiliate are high and the home and host markets are relatively similar in terms of intermediate goods. Affiliates established by M\&As are likely to have stronger links with domestic suppliers than those established by greenfield investment [UNCTAD 2000, Scott-Kennel and Enderwick 2001], since the former may find established linkages that are likely to retain if they are efficient. Linkages vary significantly by industry. In the primary sector, the scope for vertical linkages is often limited, due to the use of continuous production processes and the capital intensity of operations. In manufacturing, the potential for vertical linkages are broader, depending on the extent of intermediate inputs to total production and the type of production processes [Lall 1980].

Scott-Kennel examines linkage formation between foreign affiliates and domestic firms, as well as the resource flows from the parent MNE to the affiliate. Although she studies New Zealand, her findings are relevant to developing countries. New Zealand is highly dependent on natural resources, has moved away from import substitution relatively recently and is a small peripheral economy. On the other hand, it has well-developed infrastructure and high skill levels. Her results confirm that there are considerable opportunities for linkage formation when location advantages are appropriate, the extent of linkages varying by the type of FDI.

Bell \& Marin suggest some caution in applying results such as Scott-Kennel's to developing and intermediate countries. They argue that methodologies to measure and evaluate knowledge spillovers in advanced economies depends upon a concrete understanding of the interactions between processes, industrial structures, resource endowments and the like, and these have been stylised in the spillovers literature with advanced economies in mind. Using data from Argentina, they argue that a wellestablished domestic sector which has evolved independently of MNEs may mean that the traditional view that spillovers are largely one-way is simplistic. Co-location of domestic and foreign firms in intermediate economies has benefits for both groups of firms, and productivity growth in the domestic sector may not necessarily derive from MNE spillovers. Indeed, as also observed by Katrak (2002) in the case of India, 
knowledge creation mechanisms of MNE subsidiaries and domestic firms are sometimes largely independent. Better methods to measure and understand the direction and flow of knowledge is required before the controversy regarding the benefits of FDI and spillovers is settled.

Nature of MNE assets: Although it is a reasonable assumption that MNEs have superior firm-specific assets, the assets they transfer to particular host countries are not always those that the latter seeks or is able to assimilate. MNE competitive advantages derive from three types of assets. The first is associated with technology (knowledge, capabilities or machinery and equipment). The second is associated with the conduct of transactions, based on superior intra-firm hierarchies within and across national borders. The third is multinationality itself, the advantages of 'common governance'. These are transaction assets - MNEs gain rent from their superior knowledge of markets and internal governance of transactions. Thus, MNEs may have similar technologies to domestic counterparts but still out-compete them. In such cases, technological spillovers will not occur, though other types of spillovers might occur (say, through employee mobility or vertical links to suppliers) [Narula and Marin 2003].

Even where absorptive capacity exists, MNE assets may be very tacit and internal to the firms, as with transaction-type advantages. These assets cannot be acquired easily by local firms. This may go some way to explaining the findings of Bell \& Marin and their persuasive discussion about the difficulties of measuring and evaluating spillovers. As they emphasise in their paper, not all MNE subsidiaries in developing countries the same capacity to act as generators of knowledge spillovers.

\section{Absorptive Capacity}

How does the nature of location advantages determine the ability of the domestic economy to absorb spillovers from FDI? As almost all the papers in this special issue illustrate, the presence of externalities does not mean either that the domestic economy can internalize them, or that the externalities are significant in quantity or 
quality. Absorptive capacity is significant for development because it allows domestic actors to capture knowledge that exists elsewhere. Where absorptive capacity is lacking in domestic firms, they may, instead of reaping technological benefits from FDI, be ‘crowded out' [Agosin and Mayer 2000].

Capabilities in the host country context matter for the magnitude and intensity of technological upgrading. As Portelli and Narula (2004) have shown in the case of Tanzania, FDI in activities that match the comparative advantage of the host country provides greater linkages. Wider technology gaps between domestic and foreignowned activities tend to lead to less backward linkages and to lower technological content in the inputs sourced locally.

Several authors, like Findlay (1978) and Perez and Soete (1988), have noted that a minimum level of scientific and technical knowledge is required to use innovation. Below this level, the cost of adoption can be prohibitive. This is particularly true for FDI. Borensztein et al. (1998) show that, at country level, a minimum threshold of absorptive capacity is necessary for FDI to contribute to higher productivity growth. At the firm level, Narula and Marin (2003) show that only firms with high absorptive capacity are likely to benefit from FDI spillovers. Xu (2000) also shows that a country needs to reach a minimum human capital threshold level in order to benefit from technology transfer.

While insufficient absorptive capacity tends to lead to the inefficient use of technology inflows, knowledge accumulation is much more rapid once the threshold level of absorptive capacity is crossed. Simply put, technology absorption is easier once countries have "learned-to-learn" [Criscuolo and Narula 2002]. The cost of imitation increases as the follower closes the gap with the leader and the number of technologies available for imitation falls. This implies that there are diminishing returns on marginal increases in absorptive capacity as firms approach the frontier of knowledge [Narula 2004]. 
Kokko et al. (2001) highlight the role of past industrialization experience as a precondition for technology transfer. The absence of such experience is concomitant to lack of local absorptive capacity [Radosevic 1999]. For example, in Sub-Saharan Africa, the conditions that stimulate technological assimilation (such as developed human capital, adequate physical infrastructure and a dynamic business climate) are absent. This constrains the ability of African countries to master foreign technology and to compete in international markets [Mytelka 1985, Lall and Pietrobelli 2002]. The development of capacities and capabilities is key to both attracting FDI as well as to increasing MNE technological spillovers.

Narula (2004) decomposes absorptive capacity into four constituent parts: firm-sector absorptive capacity, basic infrastructure, advanced infrastructure and formal and informal institutions. Each is indispensable and each has different costs and benefits at different stages of development. Increases in absorptive capacity at earlier stages of development are associated with "generic" basic infrastructure and increases in technological capacity generally have positive welfare effects. For example, increases in the percentage of population with primary and secondary education have numerous welfare benefits, as does the provision of infrastructure. Investment in such resources has large multiplier effects.

\section{Taking a Systems View to Absorption and Industrial Development}

Several contributions here (Mytelka \& Barclay, Barnes \& Lorentzen, Bell \& Marin and Rasiah) stress that industrial development and absorptive capacity must be seen from a 'systems' view. By this we mean that while learning and absorption take place at the firm level, the success or failure of individual firms occurs within a "system". ${ }^{1}$ Within a system, there exists a broad knowledge base outside industrial enterprises; this base is central to technological accumulation by industry. Leaning and innovation involve complex interactions between firms and their environment. The environment consists of the firms' networks of direct customers and suppliers but it stretches much further. It also includes the broader factors shaping their behaviour and activities: the social and cultural context; the institutional and organizational 
framework; infrastructure; knowledge creating and diffusing institutions, and so on. This is the essence of the systems approach to technology.

"System" does not necessarily mean that the influences on industrial innovation are systematically organized [Narula 2003]. To put it simply, “system” means a regularly interacting or interdependent group forming a unified whole. A system is in most cases the serendipitous intertwining of institutions and economic actors that defines the stock of knowledge in a given location [Etzkowitz and Leydesdorff 2000]. For instance, changes in the educational policies of the government are likely to affect other actors and institutions, and influence the process and extent of technological learning in the future.

In a system, the efficiency of economic actors - firm or non-firm - depends on how much and how efficiently they interact amongst themselves. The means by which interactions take place are referred to as 'institutions' in the economics literature, though sociologists prefer to speak of 'social capital'. Institutions are the "sets of common habits, routines, established practices, rules, or laws that regulate the interaction between individuals and groups” [Edquist and Johnson 1997]. Institutions create the milieu within which innovation is undertaken; they establish the ground rules for interaction between economic actors and represent a sort of "culture". Institutions are associated with public sector organizations, but are not exclusively so. It is not only the creation of new knowledge but also the diffusion of extant knowledge that determine the national knowledge stock and the accumulation of national absorptive capacity.

The role of formal institutions has traditionally been considered under the rubric of political economy and has been the focus of debate on the role of the state in establishing, promoting and sustaining learning. It is not our intention to review the debate on the role of industrial policy in industrial development, highlighted in a special issue of Oxford Development Studies (Volume 31, no 1). The contributors to our special issue largely believe that governments are essential to promoting inter- 
linkages between the elements of absorptive capacity and to creating the opportunities for economic actors to absorb and internalise spillovers.

The importance of building institutions cannot be overstated: Rodrik et al. (2002) argue that efficient institutions contribute more to economic growth than location or trade. Institutions can be formal or informal. Formal institutions include the intellectual property regime, competition policy, technical standards, taxation, incentives for innovation, education and the like. Informal institutions are more difficult to define, but are associated with creating and promoting links between the various actors. For example, the government may play a role in encouraging firms to collaborate with universities or in promoting entrepreneurship.

Developing countries have switched reluctantly from inward-looking strategies with a large role for the government to market-friendly strategies that forces them to face a new multilateral milieu, one in which they have little experience and with which they are often poorly prepared to cope. Institutions continue to remain largely independent and national. While formal institutions can be legislated, modifying and developing informal institutions is a complex and slow process, since they cannot be created simply by government fiat. The developed have taken 50 years to liberalise and adjust, but even they have faced considerable inertia. They have, for instance, has yet to reform their agricultural sectors.

\section{Industrial Policy and FDI-assisted Development}

The papers in this special issue all point to a basic paradox: with weak local capabilities, industrialization has to be more dependent on FDI. However, FDI cannot drive industrial growth without local capabilities. The neoliberal approach favoured by the Washington consensus which leaves capability development to free market forces provides few realistic answers. It can result in slow and truncated technological development, with gaps between countries rising. Some upgrading does take place, but is slower and more limited than with the promotion of local capabilities. Given the 
speed at which technologies are changing and path-dependence and cumulativeness in capability building, it can lead to latecomers being mired in low growth traps.

The policy needs of capability building have not changed much. They are direct - the infant industry case to provide 'space' for enterprises to master new technologies without incurring enormous and unpredictable losses - and indirect, to ensure that skill, capital, technology and infrastructure markets meet their needs. There is also a need to coordinate learning across enterprises and activities, when these are linked in the production chain and imports cannot substitute effectively for local inputs. At the same time, technical change makes it necessary to provide more access to international technology markets; it also makes it more difficult to anticipate which activities are likely to succeed. The information needs of industrial policy rise in tandem with technological change and complexity. The greater complexity of technology does not make selectivity unfeasible. Detailed targeting of technologies, products or enterprises may be more difficult because of the pace of change, but targeting at higher levels is feasible and more necessary. Technological progress may actually make industrial policy easier in some respects: information on technological trends and markets is more readily available, more is known about the policies in successful countries and benchmarking is easier.

The spread of integrated production systems makes it more difficult and risky to take the route used by the East Asian NIEs. It is much easier for countries to attract segments of MNE activity and build upon these rather than to develop local capabilities independently. All the later entrants into globalized systems, from Malaysia to Mexico and Costa Rica, have gone the FDI route. However, as FDI regimes become more liberal, MNEs are also less willing to part with valuable technologies to independent firms.

Globalization does not do away with the need for all selective industrial policies; it only reduces the scope and raises the potential cost of some. FDI is complementary to local enterprises and capabilities after a certain level of development. Strong local capabilities raise the possibility of attracting high value systems and of capturing skill 
and technology spillovers from them; these capabilities need selective policies. Moreover, attracting export-oriented FDI increasingly requires selective promotion and targeting; the most effective targeting is undertaken by advanced economies [Loewendahl, 2001].

Lall (1996, 1997a, 1997b, 2003) and Wade (1990) among others point to the need of a holistic approach to selecting and leveraging sectors for dynamic growth along with stable government, transparent policies and basic infrastructure and skills. The role of governments as a market facilitator and provider of complementary assets is more critical [Narula 2003].

The provision of basic location advantages is perhaps most significant for precatching up and catching-up economies, where firms rely on governments to provide public and quasi-public goods. As countries reach a threshold level of technological capabilities and start catching up in earnest, governments need to provide more active support. This means developing specific industries and technological trajectories, so that their location advantages grow less 'generic'. In other words, their role as market facilitator and provider of complementary location-specific advantages becomes more critical [Dunning 1997, Stopford 1997].

The paper by Rasiah undertakes a comparative analysis of export performance and technological capabilities of foreign and local firms in three Asian countries. He suggests that the role of governments is critical to providing the necessary technology infrastructure, support for technology activity in the form of subsidies, training and R\&D organizations, and special programs to foster firm-university relationships. By doing so, governments create a 'strong latent capacity to stimulate technology transfer' by MNEs.

While several papers contribute to the discussion of the role of government in promoting FDI-assisted development, they do not point to an optimal set of policies. Lauridsen discusses the role of the state in Thailand. As he illustrates, it is one thing that appropriate policies are adopted; it is quite another whether they are effectively 
implemented. Political and social constraints can severely affect the outcome. A similar point is also made by Mytelka \& Barclay, using the contrasting examples of Costa Rica and Trinidad. Mortimore \& Vergara argue that it is important to have policies to induce MNEs to improve and upgrade capabilities to sustain more sophisticated industrial activities, not just by attracting the initial investment but also but also by encouraging MNEs to realize dynamic comparative advantages in the host economy.

Liberalisation provides the policy framework for globalisation. However, it often administers a major 'shock' to industries and institutions in most countries, introducing not just import competition and new actors (MNEs), but also calling for the restructuring of institutions (legal codes, political structures, policy orientation). Sudden exposure to the full force of international competition will not facilitate their institutional adjustment, as illustrated by the chaotic state of the ex-Soviet economies. FDI does not necessarily help institutional restructuring. As Kogut (2000: 34) notes:

Institutions, however, do not travel by the arteries of multinational corporations. They reflect patterns of behaviour that are inscribed in legal codes and political and economic relationships. Outside the power of any one actor to change, institutions are social agreements that guide and coordinate the interdependent acts of economic actors in a country.

The lack of success of liberalization in many countries reflects both the failure to integrate aspects of policy in a systemic way and the difficulty of changing inherited institutions. Most countries have attempted to graft the new model on to the remnants of the old one, because interest groups and institutions are resistant or expensive to change. While liberalization has helped correct many inefficiencies, improving macro-economic fundamentals and reducing the excessive role of the state in industrial activity, it has also led to a rapid and overzealous reduction in the state's provision of the public and quasi public goods that are necessary for industrial development [Ramos 2000, Katz 2001, Alcorta 2000]. 
The debate on how best to respond to the industrial policy challenges in an interdependent world continues. The contribution by Chang emphasises the lack of an alternative model to infant-industry protection, which he argues is a case of 'kicking away the ladder' by the rich countries. Chang acknowledges that a return to the import-substitution model is no longer feasible, because globalisation is largely irreversible, and that international competition does help reduce inefficiencies. Nonetheless, catch-up through infant industry promotion has always been the bedrock of industrial development [see also Chang 2002, and Wood et al 2003 for further discussion] and as yet no clear alternative has presented itself.

It is difficult to see how host countries that have FDI can tap its potential fully without such strategies as local content rules, incentives for deepening technologies and functions, inducements to export and so on. Performance requirements have been deployed inefficiently in many countries, but, as with protection, they have also been used very effectively by others. Catching up implies the absorption and mastery of existing technology, and this implies that there is knowledge available for imitation and that rules permit firms to imitate. Multilateral and bilateral agreements such as TRIPs, TRIMs and SCM severely limit the potential for developing countries to use traditional policy instruments to protect learning and promote reverse engineering, so reducing opportunities to build domestic industrial capacity.

The paper by Malhotra addresses the agenda of FDI and development from the perspective of supra-national agreements. He highlights the need to rethink agreements such as TRIMs and TRIPS in light of the human development agenda, rather than the current singular focus on economic growth. Malhotra also argues that multilateral and bilateral investment agreements have dubious benefits since they restrict the policy autonomy of developing countries, and may increase transaction costs, while simultaneously increasing opportunity costs.

Several papers in this issue highlight that while policies such as local content requirements may no longer be feasible, a variety of 'soft' policies remain available to host countries to encourage MNEs to create linkages. Mortimore \& Vergara 
recommend the targeting of lead MNEs as a means of creating clustering. They illustrate their argument with two contrasting cases, one of which achieved impressive results, and the other which failed. Lauridsen and Mytelka \& Barclay also present suggestions for the use of soft policy options.

The critical issue facing the development community in industrialization is whether the degree of policy freedom left to developing countries is sufficient to promote FDI assisted industrial development without strong policy intervention. WTO rules do not prohibit all selective interventions, only those that affect trade. However, other forces making for liberalization are less formal and rule-based (structural adjustment programmes, bilateral trade and investment agreements and pressures by rich countries) and they are as powerful. Together they constitute a formidable web of constraints on governments mounting industrial policy. Some constraints may be useful and may prevent the more egregious forms of intervention that have led to inefficiency, rent-seeking and technological sloth. They are also beneficial to countries with strong capabilities developed behind protective barriers: India, Brazil or China should accelerate liberalization if they can combine this with a strategy to restructure activities and enter promising new activities.

The permissible tools are probably not enough to foster the rapid development of technological capabilities. They may force poor countries with weak industrial bases to become over-dependent on FDI to drive industrial development. This cannot meet a major part of industrialization needs. Even countries able to plug into global production systems can only do so as providers of low-level labour services; subsequent deepening may be held back by constrictions on capability development. For developing countries with a capability base the rules can deter diversification into new technologies and activities. In general, the rules threaten to freeze comparative advantage in areas where capabilities exist at the time of liberalization, yielding a relatively short period of competitive growth before the stock is 'used up'. Subsequent upgrading of competitiveness is likely to be slower than if governments had the tools to intervene selectively. 


\section{Concluding Remarks}

Our objective in writing this introductory paper has been to place the various contributions to this special issue in the context of the broad range of interdisciplinary research on FDI and development.

To return to the question posed in the title of this paper, 'do we need a new agenda?', the papers here suggest that although the mechanisms underlying FDI and development have not changed, the intricacies of these mechanisms need to better understood if they are to prove beneficial. All the contributors here are also unanimous in their scepticism of the Washington consensus and the rather simplistic view taken by certain mainstream economists that FDI is a sine qua non for economic development. Market forces cannot substitute for the role of governments in developing and promoting a proactive industrial policy. MNEs and FDI may well lead to an increase in productivity and exports, but they do not necessarily result in increased competitiveness of the domestic sector or increased industrial capacity, which ultimately determines economic growth in the long run. FDI per se does not provide growth opportunities unless a domestic industrial sector exists which has the necessary technological capacity to profit from the externalities from MNE activity. This is well illustrated by the inability of many Asian countries that have relied on a passive FDI-dependent strategy to upgrade their industrial development.

At the same time, the findings in this volume also suggest that liberalisation and increasing cross-border economic activity associated with globalisation are largely irreversible, and have changed the 'rules of the game'. This implies that traditional policy tools are not as effective as they might have been in the past. However, it is still a matter of conjecture what the long-term developmental effects of many of the supra-national and bilateral agreements will be. In this regard, our contributors would suggest, we do need a new agenda if FDI is to be leveraged efficiently to promote development. 


\section{Notes}

${ }^{1}$ These have been referred to as innovation systems (see e.g., Lundvall 1992, Edquist 1997) or learning systems (Lall 1992, Viotti 2002). 


\section{References}

Agosin, M. and R. Mayer, 2000, 'Foreign Investment in Developing Countries: Does it Crowd in Domestic Investment?’, UNCTAD Discussion Papers No. 146.

Alcorta, L., 2000, 'New Economic Policies and the Diffusion of Machine Tools in Latin America', World Development, Vol. 28, pp. 1657-72.

Altenburg, T., 2000, 'Linkages and Spillovers between Transnational Corporations and Small and Medium-sized Enterprises in Developing Countries: Opportunities and Best Policies', in UNCTAD, TNC-SME Linkages for Development: IssuesExperiences-Best Practices, New York and Geneva: United Nations.

Benito, G., B. Grogaard and R. Narula, 2003, 'Environmental Influences on MNE Subsidiary Roles: Economic Integration and the Nordic countries', Journal of International Business Studies, Vol.34, pp.443-56).

Blomstrom, M and A. Kokko, 1997, "How Foreign Investment Affects Host Countries”, Policy Research Working Paper, The World Bank.

Borenzstein, E., J. De Gregorio and J.W. Lee, 1998, 'How does Foreign Direct Investment Affect Economic Growth?', Journal of International Economics, Vol. 45, pp.115-35.

Bruton, H., 1998, 'A Reconsideration of Import Substitution', Journal of Economic Literature, Vol. 36, pp. 903-36.

Carillo, J., 2001, 'Foreign Direct Investment and Local Linkages: Experiences and the Role of Policies. The Case of the Mexican Television Industry in Tijuna', UNCTAD (Geneva: UNCTAD), mimeo.

Chang, Ha-Joon, 2002, 'Kicking Away the Ladder: Development Strategies in Historical Perspective', London: Anthem.

Criscuolo, P. and R. Narula, 2002, 'A Novel Approach to National Technological Accumulation and Absorptive Capacity: Aggregating Cohen and Levinthal', MERIT Research Memorandum 2002-16.

Driffield, N. and A.H. Mohd Noor, 1999, 'Foreign Direct Investment and Local Input Llinkages in Malaysia', Transnational Corporations, Vol. 8, No.3, pp. 1-24. 
Dunning, J.H. and R. Narula, 2004, Multinational and Industrial Competitiveness: A New Agenda, Cheltenham: Edward Elgar

Dunning, J.H., 1997, 'A Business Analytic Approach to Governments and Globalisation', in J.H. Dunning (ed.), Governments, Globalisation and International Business, Oxford: Oxford University Press, pp. 114-31.

Dunning, J.H. and R. Narula, 1996, (eds.), Foreign Direct Investment and Governments: Catalysts for Economic Restructuring, London: Routledge.

ECLAC, 2000, Foreign Investment in the Latin American and the Caribbean 1999, United Nations, Santiago

ECLAC, 2001, Foreign Investment in the Latin American and the Caribbean 2000, United Nations, Santiago.

Edquist, C., 1997, Systems of Innovation, London: Pinter.

Edquist, C. and B. Johnson, 1997, 'Institutions and Organisations in Systems of Innovation', in C. Edquist, (ed.), Systems of Innovation: Technologies, Institutions and Organisations, London and Washington: Pinter.

Findlay, R., 1978, 'Relative Backwardness, Direct Foreign Investment and the Transfer of Technology, A Simple Dynamic Model', Quarterly Journal of Economics, Vol. 92, pp.1-16.

Ganiatsos, T., 2000, 'Global Component Outsourcing in Developing Countries' Electronics and Automotive Industries', Paper submitted to the UNCTAD Expert Meeting on the Relationship between SMEs and TNCs to ensure the competitiveness of SMEs (Geneva), 27-29 November, mimeo.

Gorg, H. and F. Ruane, 1998, 'Linkages between Multinationals and Indigenous Firms: Evidence for the Electronics Sector in Ireland', Trinity Economic Paper Series, Technical Paper No. 98/13.

Hagedoorn, J. and R. Narula, 2001, 'Evolutionary Understanding of Corporate Foreign Investment Behaviour: US Foreign Direct Investment in Europe', in R. Narula (ed.), International Trade and Investment in a Globalising World, New York: Pergamon.

Katrak, H., 2002, 'Does Economic Liberalisation Endanger Indigenous Technological Developments? An Analysis of the Indian Experience', Research Policy, Vol. 31, pp. 19-30. 
Katz, J., 2001, 'Structural Reforms and Technological Behaviour. The Sources and Nature of Technological Change in Latin America in the 1990s', Research Policy, Vol. 30, pp. 1-19.

Kogut, B., 2000, 'The Transatlantic Exchange of Ideas and Practices: National Institutions and Diffusion', les notes de l'ifri No. 26.

Kokko, A., M. Zejan and R. Tansini, 2001, 'Trade Regimes and Spillover Effects of FDI: Evidence from Uruguay’, Welwirtschaftliches Archiv, Vol. 137, pp. 124-49.

Lall, S. and C. Pietrobelli, 2002, Failing to Compete. Technology Development and Technology Systems in Africa, Edward Elgar.

Lall, S., 1980, 'Vertical Inter-firm Linkages in LDCs: An Empirical Study', Oxford Bulletin of Economics and Statistics, (August), pp. 209-22.

Lall, S., 1992, 'Technological Capabilities and Industrialization', in World Development, Vol. 2, No. 2, pp.165-86.

Lall, S., 1996, Learning from the Asian Tigers, Basingstoke: Macmillan.

Lall, S., 1997a, 'East Asia', in J.H. Dunning (ed.), Governments, Globalisation and International Business, Oxford: Oxford University Press, pp. 407-30.

Lall, S., 1997b, 'Policies for Industrial Competitiveness in Developing Countries: Learning from Asia', Report prepared for the Commonwealth Secretariat, Oxford.

Lall, S., 2003, 'Foreign Direct Investment, Technology Development and Competitiveness: Issues and Evidence', in S. Lall and S. Urata (eds.), Competitiveness, FDI and Technological Activity in East Asia, Cheltenham: Edward Elgar, pp. 12-56.

Loewendahl, H., 2001, ‘A Framework for FDI Promotion', Transnational Corporations, Vol. 10, No. 1, pp. 1-42.

Lundvall, B. (ed.), 1992, National Systems of Innovation: Towards a theory of Innovation and Interactive Learning, London: Pinter Publishers.

McAleese, D. and D. McDonald, 1978, 'Employment Growth and the Development of Linkages in Foreign-owned and Domestic Manufacturing Enterprises', Oxford Bulletin of Economics and Statistics.

Mortimore, M., 2000, 'Corporate Strategies for FDI in the Context of Latin America's New Economic Model', World Development, Vol. 28, No.9, pp. 1611-26. 
Mytelka, Lynn K., 1985, 'Stimulating Effective Technology Transfer: The Case of Textiles in Africa', in N. Rosenberg and C. Frischtak (eds.), International Technology Transfer, , New York: Praeger.

Narula, R., 1996, Multinational Investment and Economic Structure, London: Routledge.

Narula, R., 2003, Globalisation and Technology, Cambridge: Polity Press.

Narula, R., 2004, 'Understanding Absorptive Capacities in an Innovation Systems Context: Consequences for Economic and Employment Growth', MERIT Research Memorandum 2004-003.

Narula, R. and Dunning, J.H.. 2000, 'Industrial Development, Globalisation and Multinational Enterprises: New Realities for Developing Countries', Oxford Development Studies, Vol. 28, No.2, pp.141-67.

Narula, R. and A. Marin, 2003, 'FDI Spillovers, Absorptive Capacities and Human Capital Development: Evidence from Argentina', MERIT Research Memorandum 2003-16.

Perez, C. and L. Soete, 1988, 'Catching-up in Technology: Entry Barriers and Windows of Opportunities, in Dosi et al., Technical Change and Economic Theory, New York: Columbia University Press.

Portelli, B. and R. Narula, 2003, 'Foreign Direct Investment though Acquisitions and Implications for Technological Upgrading. Case evidence from Tanzania', Globalisation as a Transformative Process Working Paper Series 05/03, September 2003, TIK, University of Oslo, Norway.

Radosevic, S., 1999, International Technology Transfer and Catch-up in Economic Development, Cheltenham, UK: Edward Elgar.

Ramos, J., 2000, 'Policy Directions for the New Economic Model in Latin America', World Development, Vol. 28, pp. 1703-17.

Rasiah, R., 1994, 'Flexible Production Systems and Local Machine Tool Subcontracting: Electronics Component Multinationals in Malaysia', Cambridge Journal of Economics, Vol.18, pp. 279-98.

Rasiah, R., 1995, Foreign Capital and Industrialization in Malaysia, London: Macmillan. 
Reuber, G.L., H. Crookell, M. Emerson and G. Gallais-Hamonno, 1973, Private Foreign Investment in Development, Oxford: Clarendon Press.

Ritchie, B., 2002, 'Foreign Direct Investment and Intellectual Capital Formation in South East Asia’, OECD Technical Papers No 194.

Rodriguez-Clare, A., 1996, 'Multinationals, Linkages, and Economic Development', American Economic Review, Vol. 85, pp.852-73.

Rodrik, D., A. Subramanian and A. Trebbi, 2002, 'Institutions Rule: The Primacy of Institutions over Geography and Integration in Economic Development, NBER Working Paper 9305.

Scott-Kennel, J. and P. Enderwick, 2001,' Economic Upgrading and Foreign Direct Investment: Exploring the Black Box of the IDP', Mimeo, University of Waikato, New Zealand.

Stopford, J., 1997, 'Implications for National Governments', in J.H. Dunning (ed.), Governments, Globalisation and International Business, Oxford: Oxford University Press, pp. 457-80.

UNCTAD, 2000, World Investment Report 2000 - Cross-Border Mergers and Acquisitions and Development, United Nations, New York and Geneva.

Viotti, E., 2002, 'National Learning Systems: A New Approach on Technological Change in Late Industrializing Economies and Evidences from the Cases of Brazil and South Korea', in Technological Forecasting and Social Change, Vol. 69, pp. 653-80.

Wade, R., 1990, Governing the Market: Economic Theory and the Role of Government in East Asian Industrialization, Princeton NJ: Princeton University Press.

Wood, A., J. Roberts, R. Wade and S. Lall, 2003, 'Symposium on Infant Industries', Oxford Development Studies, Vol. 31, pp.3-20.

Xu, B., 2000, 'Multinational Enterprises, Technology Diffusion, and Host Country Productivity Growth', Journal of Development Economics, Vol. 62, pp. 477-93. 